\title{
O TÚMULO DO GENERAL: HISTÓRIA E ARTE NO BRITISH CEMETERY DO RECIFE
}

\section{Davi Kiermes Tavares}

Professor do IFBA

dakita@uol.com.br

José Paulo Seifert Brahm

Aluno do PPGMP da UFPel/Bolsista CAPES

josepbrahm@hotmail.com

Ronaldo Bernardino Colvero

Professor da UNIPAMPA/PPGMP UFPel

rbcolvero@gmail.com

\section{RESUMO}

O artigo focaliza o túmulo do General Abreu e Lima - estabelecido no British Cemetery do Recife, Pernambuco - segundo a conformação da história e da arte que o emolduram. Viabiliza-se a partir do suporte teórico e dos dados levantados em pesquisa empreendida durante o curso de mestrado do Programa de Pós-Graduação em Memória Social e Patrimônio Cultural da Universidade Federal de Pelotas, anos 2014-2016. Utiliza, em sua fundamentação histórica e artística, argumentos de autores como Valladares (1972), Chacon (1983), Rodrigues (1997; 2005), Tavares (2015; 2016), Borges (2002), Coli (1995), entre vários. Conclui que o túmulo remete a uma história de vida plena de desafios e superações até o final, ao mesmo tempo que estimula o olhar, de quem o contempla, para além da materialidade e do tempo.

Palavras-chave: Abreu e Lima; História; Arte; British Cemetery.

\section{INTRODUÇÃO}

Uma construção tumular pode ser (e efetivamente é) um paraíso da comunicação e até mesmo da semiótica, pois está repleto de informações e de sinais, através dos quais 
se pretende algum tipo de mensagem. Grandes mausoléus, com pomposas estátuas e colunas monumentais, por exemplo, informam aos visitantes e frequentadores de cemitérios que ali está enterrado alguém que enquanto vivo ocupava uma posição de prestígio social. Isso pode ser reforçado pelos epitáfios, por placas comemorativas, bustos, brasões e outros símbolos que destacam as qualidades e a posição social ou profissional do falecido. A propósito, cabe lembrar que a divisão das classes sociais não termina após a morte: as posições sociais permanecem inalteradas no cemitério, lugar onde é perfeitamente possível identificar - em grande parte dos casos - os "bairros" ricos, pobres e das classes médias. ${ }^{1}$

Por isso, um túmulo monumental estabelecido no British Cemetery (chamado popularmente "Cemitério dos Ingleses"), na cidade do Recife, capital do Estado de Pernambuco, região Nordeste do Brasil, é o objeto deste artigo e focalizado a partir da conformação da história e da arte que o emolduram. O túmulo a que se faz referência abriga os restos mortais do militar, intelectual, escritor e ativista social pernambucano (e muitos outros qualificativos poder-se-ia colocar) José Ignácio de Abreu e Lima, o "general das massas"; ${ }^{2}$ o quase Patrono do Exército Brasileiro. ${ }^{3}$

Após uma vida de muitos desafios e enfrentamentos, entre os quais o de lutar ao lado de Simón Bolívar pela libertação da Colômbia, Venezuela, Equador, Peru e Bolívia, volta ao Recife, ainda vivendo ali por vários anos, e falece. Tem sepultura negada em "chão sagrado" pelo bispo diocesano de Recife e Olinda Dom Francisco Cardoso Ayres. Seu corpo foi, então, inumado no Cemitério dos Ingleses do Recife (Figura 1), que o acolheu. Episódio esse que, na época, repercutiu na opinião pública do Recife, em todo o Império brasileiro, chegando a reverberar em Portugal. Posteriormente, seu túmulo é distinguido por construção singular, que é sobreposto à cova.

\footnotetext{
${ }^{1}$ Esclareça-se que tal comprovação se coaduna ao cemitério chamado oitocentista, romântico ou tradicional - que teve seu apogeu na segunda metade do século XIX a tal ponto de ser considerado "o céu da memória" (CATROGA, 1999). O cemitério dito moderno obedece outra concepção construtiva e imagética.

${ }^{2}$ Epíteto que lhe foi atribuído, no sentido pejorativo, pelo jornalista republicano Evaristo da Veiga, com quem travou apaixonadas polêmicas pela imprensa, no Brasil Império (CHACON, 2007).

${ }^{3}$ Quando da escolha do Patrono, três nomes se destacaram: Luiz Alves de Lima e Silva, o Duque de Caxias, o Pacificador; Manuel Luiz Osório, o Visconde e Marquês de Herval, o Centauro dos Pampas; e ele, Abreu e Lima, o Libertador de Nova Granada. Fato expressivo e que, por si só, dá a medida da grandeza do personagem. Cf. Lima Filho \& Pereira (1975, p. 21).
} 


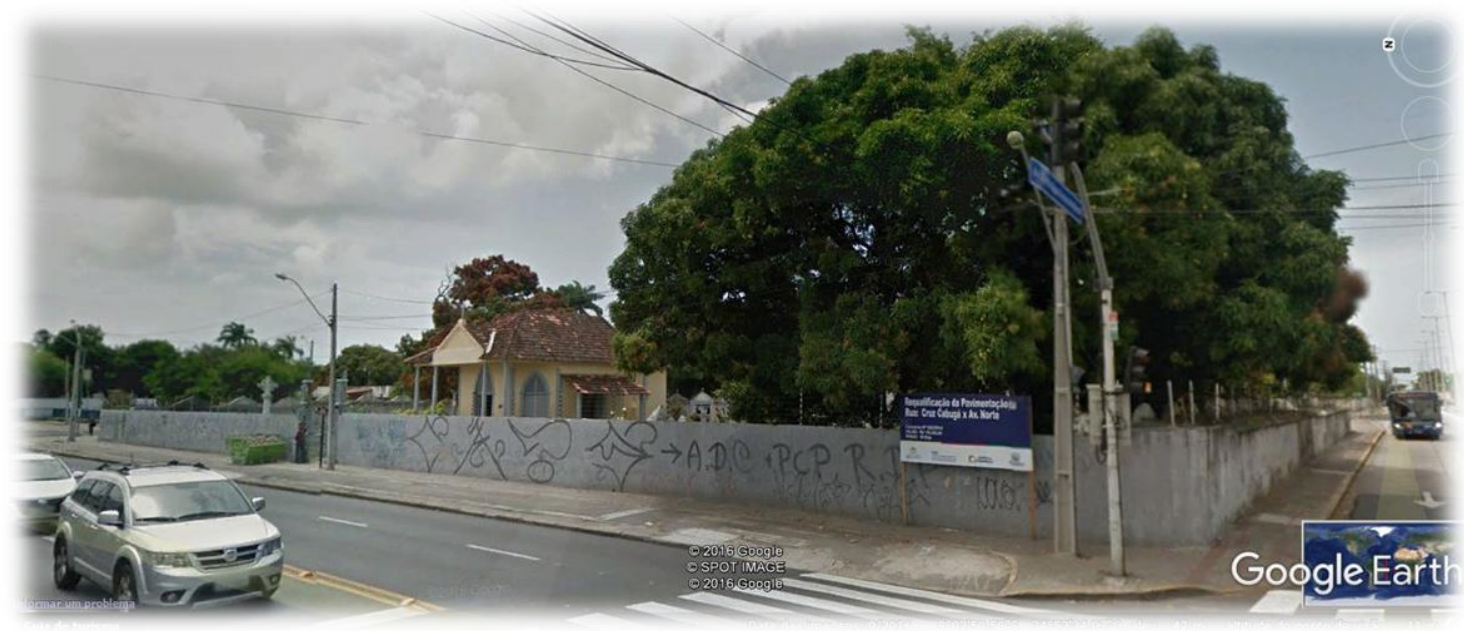

Figura 1: Imagem atual do British Cemetery do Recife.

Fonte: Google Earth, 2016.

Quando em trabalho de campo realizado no mencionado cemitério, decorrente de pesquisa sob o auspício do Programa de Pós-Graduação em Memória Social e Patrimônio Cultural da Universidade Federal de Pelotas, curso de mestrado, ${ }^{4}$ durante os anos de 2015 e 2016, chegou-se ao conhecimento in loco do mausoléu.

A riqueza da história de vida do personagem, a querela do seu sepultamento, o monumento funerário e seu conteúdo artístico erigido em sua memória foram conhecimentos adquiridos em derivação, os quais oportunizaram a investigação e a perspectiva de análise. O que segue nas próximas páginas é decorrência disso e obedecerá à disposição dos assuntos mencionados.

\section{A HISTÓRIA...}

Outrora, muito já foi escrito sobre o cidadão brasileiro José Ignácio de Abreu e Lima - ou general Abreu e Lima, como ficou mais conhecido. Cartas, discursos, crônicas, reportagens, ensaios, biografias, livros inteiros avultam. Dentre os que se debruçaram sobre sua vida e feitos, vale mencionar Francisco Augusto Pereira da Costa (pioneiro em abordá-lo, em 1882) e Vamireh Chacon (autor de cuidadosa biografia

\footnotetext{
${ }^{4}$ A pesquisa redundou em dissertação intitulada "Uma Necrópole Esquecida e os Valores Para a Sua Conservação: o British Cemetery do Recife em perspectiva".
} 
lançada sobre o personagem em comento, publicada em 1983 - primeira edição). Seus argumentos são utilizados como principais referências nesta parte do texto.

Todavia, em tempos mais recentes, a sua memória está como que obliterada. As gerações de brasileiros das últimas quatro décadas, pelo menos, nada ou pouco sabem sobre sua vida. Como tantos outros personagens míticos nacionais, Abreu e Lima está por merecer um pleno e contínuo (re)conhecimento. Ainda que, aqui e ali, existam tributos a sua memória e importância na e para a história do país. Um município no Estado de Pernambuco; ${ }^{5}$ uma avenida na cidade de Pelotas, $\mathrm{RS} ;^{6}$ uma refinaria de petróleo (a Refinaria Abreu e Lima teve iniciada sua construção em 2005, em Suape, município de Ipojuca, Estado de Pernambuco - fruto da parceria entre o Brasil, sob a presidência de Luiz Inácio Lula da Silva, e a Venezuela, sob a presidência de Hugo Chávez $)^{7}$ são alguns exemplos que podem ser evocados em auxílio.

Convém, por isso, delinear primeiramente, ainda que de maneira sucinta, a sua trajetória existencial.

\section{...de sua vida e morte}

Para quem nunca leu, ou leu minimamente ou, ainda, nada sabe, sobre Abreu e Lima, diga-se que nasceu no Recife a 6 de abril de 1794 (no Engenho Casa Forte), e foi um cidadão brasileiro eminente, "[...] típico personagem do século XIX, não só um romântico apaixonado, mas também um bravo guerreiro e um cidadão que luta e sente saudades de sua Pátria” (OLIVEIRA, 2015, p. 12).

Filho de família com posses econômicas, a sua cuidadosa instrução, concluída em Olinda, por volta de 1811, foi ministrada pelos mais afamados mestres da época. Estudou latim, filosofia, retórica, francês e inglês. Como reforço, frequentava o curso regimental de artilharia, e estudava literatura e grego com o seu pai, José Ignácio

\footnotetext{
${ }^{5}$ Trata-se do município de Abreu e Lima, o qual dista $19 \mathrm{~km}$ do Recife - capital do Estado de Pernambuco.

${ }^{6}$ É a Avenida Abreu e Lima, localizada no bairro Três Vendas. CEP 96065-740. Disponível em: <https://www.google.com.br/webhp?sourceid=chrome-instant\&ion=1\&espv=2\&ie=UTF$8 \# \mathrm{q}=$ avenida+abreu+e+lima+em+pelotas $>$ Acesso em: 20 out. 2016.

${ }^{7}$ Ver, por exemplo, a reportagem "Refinaria Abreu e Lima não está pronta após mais de 8 anos de obras". Disponível em: <http://g1.globo.com/pernambuco/noticia/2016/04/refinaria-abreu-elima-nao-esta-pronta-apos-mais-de-8-anos-de-obras.html> Acesso em: 20 out. 2016.
} 
Ribeiro de Abreu e Lima, de origem nobre, conhecido por todos pela alcunha de Padre Roma. $^{8}$

Em 1812, Abreu e Lima ingressou na Academia Real Militar do Rio de Janeiro, recebendo, quatro anos após, a patente de capitão em artilharia, sendo, então, destacado para servir em Angola (África). Em dezembro de 1816, volta ao Recife. É envolvido num motim contra o Ouvidor de Olinda, sendo preso. Mas, recorrendo da prisão, vai para a província da Bahia (Salvador), para onde havia feito o "agravo da pronúncia de prisão" (recorrência judicial da prisão), em princípios de fevereiro de 1817. Ao chegar ali, é recolhido à Fortaleza de São Pedro por ordem do Conde dos Arcos, governador daquela província.

Nesse mesmo ano, ao eclodir no Recife, no dia 6 de março, a Revolução Pernambucana, cujos objetivos centrais eram a República e a Independência do Brasil, figurou como um dos principais chefes o seu pai, o Padre Roma, que, após a vitória dos legalistas imperiais, ao chegar à Bahia no caráter de comissário dos pernambucanos, foi denunciado, preso e, por fim, condenado à morte (executado, em 29 de março de 1817, no Largo da Pólvora). Abreu e Lima foi obrigado a assistir ao fuzilamento do pai. Esse acontecimento além de marcar profundamente a vida do futuro general, levou sua família à ruína e a dispersão (CHACON, 1983).

Depois dessa marcante experiência, ele ainda passou alguns meses na prisão, em companhia de seu irmão Luís Ignácio de Abreu e Lima e de outros presos remetidos de Pernambuco. Em outubro de 1817, escapa da prisão com seu irmão, auxiliado pela maçonaria, embarca para os Estados Unidos da América do Norte, aonde chegaram em fevereiro de 1818. Estava decidido: lutaria pelo fim do regime colonial na América Latina. Com tal propósito separa-se do irmão e viaja para La Guairá, na Venezuela. De lá, escreve a Simon Bolívar, oferecendo seus serviços militares como capitão (Figura 2).

\footnotetext{
${ }^{8}$ Ordenado Padre, em Roma, pelo Cardeal Chiaramonti, futuro papa Pio VII, mesmo que tivesse posteriormente largado a batina para se casar, ficou "eternizado" como Padre Roma.
} 


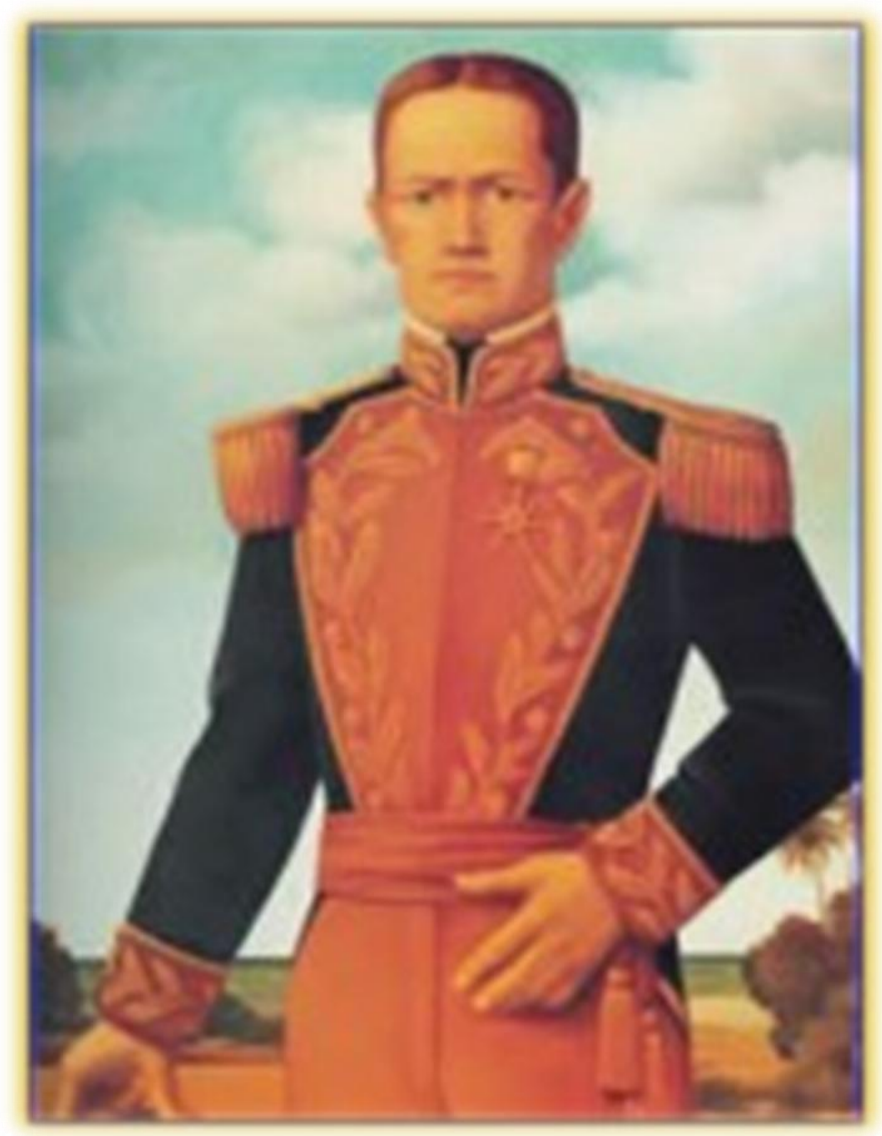

Figura 2: Retrato de Abreu e Lima.

Fonte: Instituto Abreu e Lima. Disponível em: <http://www.institutoabreuelima.com.br/category/fotos/>. Aceso em: 15 nov. 2015.

Em 1819, em Angostura (hoje Cidade de Bolívar, na Colômbia), Simon Bolívar o aceitou no posto pretendido. Em seguida e durante um curto espaço de tempo, Abreu e Lima colaborou no Correo del Orinoco, um semanário comprometido com o ideário de Bolívar, inclusive nele publicando diversas matérias sobre a luta pela independência no Brasil, mormente em Pernambuco. Ainda em 1819, segue para a linha de frente, lutando sob o comando de Bolívar nas principais batalhas que conduziram os insurretos à vitória contra os colonizadores. Entre outras, Abreu e Lima participou de batalhas memoráveis como a de Boyaca (1819) e a Carabobo (1821): a primeira conduziu à proclamação da República da Colômbia; a segunda, à libertação da Venezuela.

Inspirado pelo modelo federalista norte-americano, Simon Bolívar sonhava forjar as bases da unidade da América do Sul pela construção de uma federação de nações da região, forma de mantê-la forte e solidária. Bolívar conseguira organizar a 
Grã-Colômbia reunindo Venezuela, Nova Granada (Colômbia) e o Equador, mas o projeto da incorporação de novas nações não vingou, pois, diversamente dos Estados Unidos da América do Norte, as tendências nacionalistas impediram o aprofundamento do projeto. A Grã-Colômbia em pouco tempo chegou ao fim.

Com o desmoronamento do sonho de integração, em 1830, Simon Bolívar foi afastado do poder e deixou a vida pública, vivendo os seus últimos dias no exílio, em Santa Marta (Colômbia). Bolívar, "El Libertador", um dos maiores heróis da América Latina, que entrou na política rico e dela saiu pobre e frustrado, faleceu de tuberculose aos 47 anos de idade, em 17 de dezembro de $1830 .^{9}$ Abreu e Lima, general e membro do Estado Maior de Bolívar, acompanhou-o até o retiro de Santa Marta, mantendo-se fiel e ao seu lado até o fim.

A situação que se seguiu à retirada de Bolívar da vida pública inviabilizou a permanência de oficiais estrangeiros nos quadros do Exército da Colômbia, que dele foram excluídos por decreto de 09 de setembro de 1831, em ato do ministro da guerra daquele país. Em decorrência, Abreu e Lima, ostentando a patente de general de brigada que lhe foi conferido por Bolívar, assim como os títulos de "Libertador da Venezuela e de Nova Granada", retorna ao Brasil, em pleno período regencial, fixando residência no Rio de Janeiro.

Na capital do Império, ligou-se habilmente a grupos de políticos e de escritores, participando de atividades culturais, o que lhe facultou a obtenção da imediata recuperação de seus direitos políticos e civis. Durante a menoridade de D. Pedro II, Abreu e Lima foi anistiado, em outubro de 1832, pela Regência que governava o país, a qual teve "por bem conceder-lhe a faculdade para que possa usar todas as condecorações, e distinções que lhe foram conferidas pelo governo da Colômbia..." (CHACON, 1983; págs. 242 e 243).

\footnotetext{
${ }^{9}$ Existe uma fortuna bibliográfica significativa e disponível sobre a vida de Simon Bolívar. Sugere-se, por ser o mais recente título em língua portuguesa (lançado no Brasil em 2015), a obra da escritora e jornalista Marie Arana, norte-americana de origem peruana e colaboradora do Washington Post, "Bolívar: o libertador da América". No livro, ela traça um dos retratos mais completos já feitos do Libertador da América, expondo com isenção política (até aonde isso é possível) todas as suas contradições: de filho da aristocracia a jovem libertário, de gênio militar a guerreiro impiedoso, de revolucionário destemido a governante despótico, de herói perseguido no final da vida a mito de povos latino-americanos. Indica-se também a biografia, com precisão enciclopédica, do venezuelano, contida em "O Libertador: a vida de Simon Bolívar", de Moacir Werneck de Castro.
} 
Reabilitado, coberto de glórias militares e de prestígio intelectual e político, resolveu voltar ao Recife, em 1844, de onde não mais se retiraria até morrer.

A publicação de parte de sua produção literária vai ocorrer a partir do momento em que se fixou definitivamente no Recife. Destacaram-se, entre outros livros, "Compêndio da História do Brasil”, "Sinopse ou Dedução Cronológica dos Fatos mais Notáveis da História do Brasil"; "História Universal desde os Tempos mais Remotos até Nossos Dias"; “A Cartilha do Povo"; "O Socialismo"; “As Bíblias Falsificadas ou Duas Respostas ao Rev. Cônego Joaquim Pinto de Campos"; "O Deus dos Judeus e o Deus dos Cristãos". ${ }^{10}$

Escrevendo sobre assuntos diversificados, mas sem perder o interesse pela atividade política, terminou envolvido nos acontecimentos que culminaram com a Revolução Praieira (movimento de caráter popular e insurrecional) de 1848, sobretudo pela participação como dirigente e redator dos jornais "Diário Novo" e "A Barca de São Pedro", órgãos divulgadores dos ideais dos praieiros. É condenado à prisão perpétua na ilha Fernando de Noronha. Após dois anos preso foi absolvido da acusação.

Quase sexagenário, solteiro, vivendo sozinho numa casa-grande no Recife, Abreu e Lima levava uma vida dedicada a escrever e à leitura de seus livros prediletos (Figura 3).

\footnotetext{
${ }^{10}$ Esses (e outros) livros, a produção jornalística e epistolar, documentos estão disponibilizados, on-line, (inclusive para download), no sítio do Instituto Abreu e Lima: <http://www.institutoabreuelima.com.br/acervo/> Acesso em: 20 ago. 2015.
} 


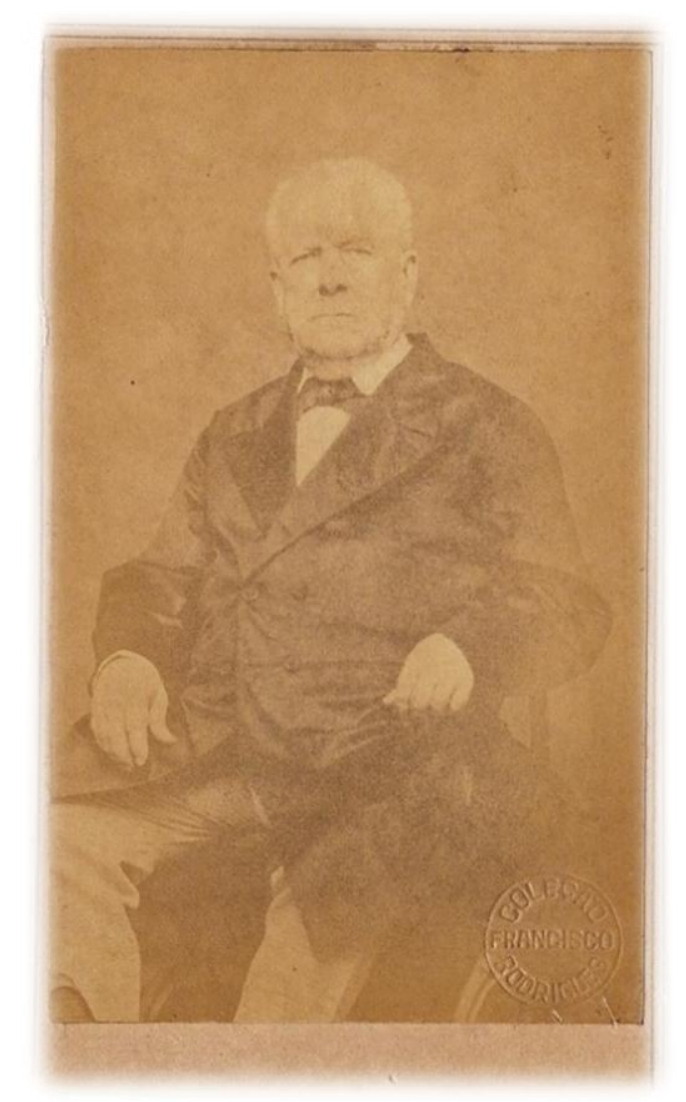

Figura 3: Fotografia do general Abreu e Lima em idade provecta.

Fonte: Fundação Joaquim Nabuco.

Disponível em:

$<$ http://digitalizacao.fundaj.gov.br/fundaj2/modules/busca/listar_projeto.php?cod=30\&f rom $=3520>$.

Acesso em: 15 nov. 2015.

Nas considerações de um biógrafo do escritor Franklin Távora (amigo e admirador do general), tem-se uma síntese daquele seu momento existencial:

Vivia modestamente, o que era de chamar a atenção porque, na verdade, fora um homem que nascera rico, pertencendo a uma das mais nobres famílias brasileiras, além de ter recebido uma educação de príncipe. Apesar de viver sempre solicitado para frequentar os mais disputados salões da sociedade pernambucana, suas conversas, de uma certa maneira, convergiam para conclusões que desapontavam os princípios estabelecidos pelos temperamentos mais conservadores que o ouviam. Era um liberal esclarecido e avançado em todos os aspectos da sociedade. O que mais empolgava os seus ouvintes talvez fosse dispor entre eles, naqueles momentos de boa prosa, de repente, de uma figura tão rara, com uma vida tomada por fatos extraordinários que parecia haver saído de outro mundo. As suas façanhas falavam de parentes e amigos íntimos, a começar de seu pai, o Padre Roma, além de outros que se chamavam Simon Bolívar, o general conquistador e 
libertador das Américas, seus generais José Antonio Páez, Francisco de Paula Santander, Antonio José de Sucre, Carlos Soublette etc. Em seguida, chegava a vez de reis e imperadores, como os casos de Luís Felipe, de França, Pedro I e Pedro II do Brasil, ministros, embaixadores, príncipes e princesas, políticos etc (AGUIAR, 1997, p. 166).

Anos antes de morrer, porém, ao falar sobre assuntos religiosos, envolvendo temas que dominavam a partir de longos e interessantes ensaios que escrevera, dando ênfase ao ecumenismo, passou à prática, visto que era um homem essencialmente de ação. Distribuiu vários exemplares do Novo Testamento, que amigos lhe mandaram de Londres, a pessoas que lhe eram amigas. Esse gesto provocou a ira do padre e deputado monsenhor Joaquim Pinto de Campos, que, dotado de um rude comportamento nas polêmicas, veio a público dizer pelos jornais que aquelas bíblias eram "falsificadas e venenosas".

Após vários embates, pelos jornais (Jornal do Recife versus Diário de Pernambuco), a polêmica entre o monsenhor e o general começou a crescer, resolvendo este escrever um livro - "As Bíblias Falsificadas ou Duas Respostas ao Sr. Joaquim Pinto de Campos pelo Cristão Velho" ${ }^{11}$ - no qual a discussão saía de aspectos pessoais tocados por parte do monsenhor Joaquim Pinto de Campos e ganhava os meandros da história secular, sendo a reforma protestante vista como uma espécie de proclamação dos tempos modernos. Aliás, essa visão de Abreu e Lima, em muitos aspectos, antecipava-se aos juízos feitos pelo sociólogo Max Weber. Foi mais além o autor de "O Socialismo". Discutiu e afirmou pontos de vista pessoais sobre vários temas que, à época, no país, estavam incólumes, verdadeiros tabus, como, por exemplo, a questão da inquisição, distinções entre as ideias sobre o que se deve entender por universalismo e romanismo dentro da história da Igreja Católica, Reforma e Contra Reforma, avanços e recuos das concepções defendidas no Concílio de Trento, entre outras. Ademais, teceu curiosos argumentos, arrimados na sua lógica de profundo conhecedor dos temas que abordava, sobre as vantagens do retorno a um cristianismo primitivo que devolvesse os

\footnotetext{
${ }^{11}$ Além desse livro, Abreu e Lima publicou outro de mesma embocadura: "O Deus dos Judeus e o Deus dos Cristãos", também de 1867. Em seguida, monsenhor Joaquim Pinto replicou os argumentos do general com um pequeno volume intitulado: "Polêmica Religiosa: Refutação ao Ímpio Opúsculo que Tem por Título 'O Deus dos Judeus e o Deus dos Cristãos' sob o Pseudônimo de Cristão Velho".
} 
princípios advogados por Santo Ambrósio, São João Crisóstomo, São Gregório de Nicéia etc.

A resposta de monsenhor Joaquim Pinto de Campos foi surpreendente. Afirmou que processaria o general Abreu e Lima pelos tribunais, acrescentando que, no entanto, preferia chicotear-lhe a cara, "a exemplo do que já havia feito ao finado capitão Manuel Joaquim do Rego Barros na freguesia do Monteiro, em plena luz do dia..." (Diário de Pernambuco, ${ }^{12}$ apud AGUIAR, 1997, p, 167).

A ofensa atingia de forma desleal a um homem idoso, com 75 anos, impossibilitado de locomover-se de seu leito, tomado por várias enfermidades, mas intelectualmente lúcido.

Após um período de crises e agravamentos da saúde, o general Abreu e Lima falece na cidade do Recife.

Aos 75 anos de idade, a 8 de março de 1869, segunda-feira, ao fim de uma manhã desbotada, tristonha e estorricante, lá pelas 11 e pouco, o general Abreu e Lima morre na modesta casinha branquela, meio sem graça, com janelas e portas azul-celeste, e de pau a pique, no bairro de Casa Amarela, no seu Recife sempre amado, tendo por única companhia e testemunha daqueles derradeiros momentos a cozinheira e amiga dona Quitéria das Chagas Vieira, que ele carinhosamente trata por doninha Quica. Chega ao fim da existência dolorosamente só, adoentado e com parcas posses, mas até os últimos instantes ele esteve, como sempre, envolvido nas mais diversas polêmicas. Morre placidamente, sentado na cadeira de palhinha defronte à sua desarrumada escrivaninha e segurando, com as duas mãos, o crucifixo e a corrente de prata que recebeu do pai, naqueles momentos finais em que este era conduzido para o pelotão de fuzilamento em Salvador. De um lado havia o tradicional Cristo na cruz e do outro os dizeres que nortearam, também, toda a sua vida de sonhos, sangue, trancos e barrancos: PER ARDUA AD ASTRA ("Pelas dificuldades alcançamos as estrelas") (BRUNI, 2010, p. 79-80, destaque do autor).

12 “Diário de Pernambuco”, Recife, 29 de outubro de 1867, na seção Comunicado. 
...de seu sepultamento ${ }^{13}$

Morto o general, eis que a cidade do Recife, de repente, despertou na manhã do dia 9 para uma realidade inusitada: o bispo Dom Francisco Cardoso Ayres negara sepultura cristã ao general Abreu e Lima.

Questionado pelo governador da província de Pernambuco à época, Brás Carneiro Nogueira da Costa e Gama, Conde de Baependi - que fora informado, pelo administrador do Cemitério Público do Recife, da morte do general e da ordem do bispo para que lhe não fosse dada sepultura -, o bispo alegou que

Sabendo do grave estado da moléstia do general Abreu e Lima, e "não constando ato algum seu que provasse arrependimento de erros que em matéria religiosa que lhe eram atribuídos', entendera ser do seu dever episcopal procurá-lo, o que fez dias antes do seu falecimento. Conduzindo a conversa com o enfermo sobre alguns pontos da doutrina católica, o bispo afirmou 'com pesar' que o general não reconhecia o mistério da Santíssima Trindade, além de repelir a idéia (sic) da confissão auricular. Não parecendo ao prelado ser prudente insistir em seus esforços naquela ocasião 'a bem da alma' daquela ovelha, 'em atenção aos sofrimentos do corpo', despedira-se comunicando ao enfermo que voltaria outra vez; tendo como resposta que ele, Abreu e Lima, 'estava pronto para recebê-lo, mas que seria inútil tratar de questões religiosas, a não ser para discutir com toda a liberdade'. Apesar disso, o bispo dispusera-se a procurar novamente o general, por acreditar que ele teria dado demonstração de deferência para com sua pessoa. Entretanto, a enfermidade teria progredido inesperadamente, chegando ao conhecimento do prelado que Abreu e Lima se achava moribundo, sem que tivesse sido possível ao bispo fazer a segunda visita ao enfermo (RODRIGUES, 2005, p. 149-150destaques da autora).

13 Todo o episódio do enterramento do general José Ignácio de Abreu e Lima é possível descortinar através das páginas do jornal católico "O Apóstolo", que circulou no Rio de Janeiro entre 1866 e 1901. Através das páginas de seu número 13, de 28 de março de 1869, ano IV, lêse a narrativa do caso feita a partir da correspondência do presidente da província de Pernambuco (1868-1869) - Brás Carneiro Nogueira da Costa e Gama, Conde de Baependi - ao ministro do Império - o conselheiro Paulino José Soares de Sousa -, transcrita na seção "Negócios Eclesiásticos - Ministério do Império - província de Pernambuco". O jornal e seus respectivos números estão disponíveis na Biblioteca Nacional, localizada no Rio de Janeiro. Aqui, valeu-se de fonte secundária - o estudo de Rodrigues (2005) que teve acesso à fonte primária - para expor aquele acontecimento. 
Face à argumentação do bispo, o governador decidiu que, mesmo respeitando a decisão episcopal, cumpria-lhe providenciar para que o cadáver tivesse sepultura decente em outro lugar. A princípio, pretendia que o sepultamento se fizesse no terreno extramuros do cemitério que não fosse bento. Entretanto, os amigos e parentes do falecido deram preferência ao cemitério protestante da cidade (receberam uma oferta por parte do cônsul-geral do Reino Unido, Sir Harry Fergusson, que, em nome da família real e de seus compatriotas do Recife, oferece o Cemitério dos Ingleses para o enterro) onde o sepultamento aconteceu no dia seguinte, sob a direção religiosa do ministro anglicano ligado à comunidade protestante da cidade.

Em tom mais emocional, essa ocorrência é assim descrita:

Os liberais, os maçons, os ateus, os progressistas, os intelectuais, os professores, os jornalistas e escritores, os jovens poetas acadêmicos mobilizaram-se em manifestações pela cidade. O bispo, porém, não cedeu. O impasse só foi resolvido no dia seguinte, quando a direção do British Cemetery decidiu acolher o corpo do general. Este cemitério, então, localizado num lugar despovoado e ermo, ainda hoje situado na estrada que vai do Recife a Olinda, é chamado de Cemitério dos Ingleses. O enterro aconteceu às 11 horas da manhã do dia 9 de março num clima de profunda emoção e de exaltados gestos de protestos populares (AGUIAR, 1997, p. 168).

O sepultamento foi possível naquele local porque, à época, o Cemitério dos Ingleses do Recife integrava um inicial conjunto de necrópoles estabelecidas no BrasilColônia destinado a receber os corpos dos súditos britânicos mortos, os quais a Igreja Católica não permitia que fossem enterrados em seus cemitérios ${ }^{14}$ por serem acatólicos (protestantes). Sua implantação, em solo brasileiro, constituía reflexo da importância, da influência e da presença significativa de ingleses, notadamente, no país de então - a qual se estenderia até meados do século XX (TAVARES, 2016).

Quanto a isso, o pesquisador Clarival do Prado Valladares (1972, p. 1335) já observou:

\footnotetext{
${ }^{14}$ As práticas de sepultamento eclesiástico foram trazidas e instituídas nas terras brasileiras pelo colonizador, sendo adotadas pela maioria da população até meados do século XIX. Elas estiveram vinculadas à prática cristã e ocidental, cuja base era a familiaridade existente entre os vivos e seus mortos, expressa na inumação no interior da comunidade, mais propriamente dentro do espaço das igrejas. Ver as explicações sobre o assunto em Rodrigues (1997), e também Castro (2007).
} 
Tinha a Inglaterra o domínio econômico (por conseguinte político) para obter de D. João VI a imediata abertura dos portos e, pelo tratado de 1810, suprimir a Inquisição Católica com permissão e garantia para os súditos Inglêses (sic) construírem ... "templos reformistas, comprometendo-se o govêrno (sic) português a proteger a independência dos cemitérios protestantes, e comprometendo-se, por sua vez, os súditos britânicos a não atacarem a religião do Estado que os acolhia, nem a fazerem obra de propagando evangélica".

Foram os cemitérios inglêses (sic) os primeiros campos-santos organizados neste País (sic), em nível de necrópole privativa de elites. O da Gamboa no Rio de Janeiro, assim como o da Ladeira da Barra em Salvador da Bahia e o de Santo Amaro em Recife datam de uma mesma época e mostram a profundidade dos interêsses (sic) britânicos neste amplo território da América Portuguesa. (Destaques do autor.)

Seis dias após o falecimento do general Abreu e Lima, uma convocação assinada por alguns de seus amigos apareceu no jornal "Opinião Nacional”, que circulou no Recife em 14 de março de 1869, trazia o seguinte teor:

Os abaixo-assinados, amigos do ilustre finado General José Ignácio de Abreu e Lima, convidam, em nome da religião cristã, a todos os parentes e amigos desse venerando pernambucano para a visita da cova, hoje, 14 do corrente, pelas 7 horas da manhã, no Cemitério Inglês. Assinados: José Ernesto de Aquino Fonseca, Eduardo de Barros Falcão de Lacerda, João Franklin da Silveira Távora (Apud AGUIAR, 1997, p. 168).

A visita à cova ocorreu sem maiores transtornos. "Na hora aprazada, um numeroso público representante de todos os níveis da sociedade local ali compareceu e reverenciou a memória do ilustre e saudoso morto. Foi uma espécie de missa de sétimo dia" (AGUIAR, 1997, p. 168).

A interdição do sepultamento do cadáver do general Abreu e Lima no cemitério público do Recife foi um acontecimento que repercutiu em todo o Império e, inclusive, em Lisboa. ${ }^{15} \mathrm{Na}$ Corte brasileira, foi um dos assuntos mais falados entre março e maio daquele ano de 1869. Afinal, era a primeira vez que um caso de recusa episcopal em receber um cidadão brasileiro tão ilustre num cemitério público era divulgado (RODRIGUES, 2005).

\footnotetext{
${ }^{15}$ Segundo Vieira (1998, p. 268), um grupo de liberais portugueses e brasileiros, em Lisboa, patrocinaram "ritos fúnebres solenes pelo general, na Igreja de Nossa Senhora das Graças, com uma 'orquestra e um grande número de padres' para mostrar sua desaprovação ao ato episcopal brasileiro".
} 
A ocorrência rendeu (e rende até hoje), discussões, debates, polêmicas... Com os simpatizantes e defensores do Bispo ou do General a esgrimirem argumentos e razões. ${ }^{16}$ Para melhor entendê-la, é necessário contextualizá-la. Concretizar essa necessidade, aqui e agora, além de fugir ao propósito deste artigo, torná-lo-ia enfadonho. Contudo, en passant, mencione-se que, naquele momento, tanto a questão do "enterramento civil", em Portugal, na segunda metade do século XIX (CATROGA, 1999), quanto à da "sepultura eclesiástica", em período análogo ao de Portugal, no Brasil (RODRIGUES, 2005), evidenciavam-se. Eram tempos da reforma ultramontana em Pernambuco (e em outras dioceses do país como o Rio de Janeiro, por exemplo), no início da década de 1870, cujo papel de executor cabia ao bispo - em choque com o liberalismo, o republicanismo, a maçonaria, o protestantismo, entrevistos nas ações e nos escrito do general e seus partidários. Eis a mirada de contemplação daquele incidente.

Toda essa narrativa conduz e favorece o enfoque do túmulo do general emoldurado pela história, já esboçada, e pela arte, que será examinada na próxima parte.

\section{A ARTE ${ }^{17}$}

Qualquer pessoa que adentre o Cemitério dos Ingleses do Recife ${ }^{18}$ tem inevitavelmente sua atenção atraída pelo túmulo-monumento situado logo à entrada, à esquerda de quem entra, ainda que desconheça a quem pertence e o motivo de sua edificação. Com dimensão de quatro metros aproximadamente (da base ao cimo), ele se distingue dos túmulos ao redor (e também dos outros que compõem o campo santo) pela cruz num círculo, sobre coluna torcida em espiral, que repousa numa base (na qual está colocada a lápide e sua inscrição) e pedestal, a ocupar toda a área reservada à carneira.

\footnotetext{
${ }^{16}$ Um dos melhores exemplos disso foi o debate que resultou no livro "O Bispo e o General" (1975), o qual, no expressar de um crítico pernambucano, contém “(...) informações históricas idôneas servidas com um inconfundível 'sense of humour"' (FONSECA, 1975, destaque no original).

${ }^{17}$ Neste trabalho, arte significa "certas manifestações da atividade humana diante das quais nosso sentimento é admirativo, isto é: nossa cultura possui uma noção que denomina solidamente algumas de suas atividades e as privilegia" (COLI, 1995, p. 8).

${ }^{18}$ Localizado na Av. Cruz Cabugá, $\mathrm{n}^{\circ}$ 876, bairro de Santo Amaro; tombado como patrimônio histórico e cultural do Estado de Pernambuco através do Decreto $n^{\circ}$ 9.131, de 23 de janeiro de 1984, assinado pelo então governador Roberto Magalhães Melo, homologando a Resolução $\mathrm{n}^{\circ}$ 15 do Conselho Estadual de Cultura.
} 
Eis uma descrição básica do túmulo do general Abreu e Lima (Fig. 4). A escultura apresenta elementos artísticos e simbólicos. ${ }^{19}$

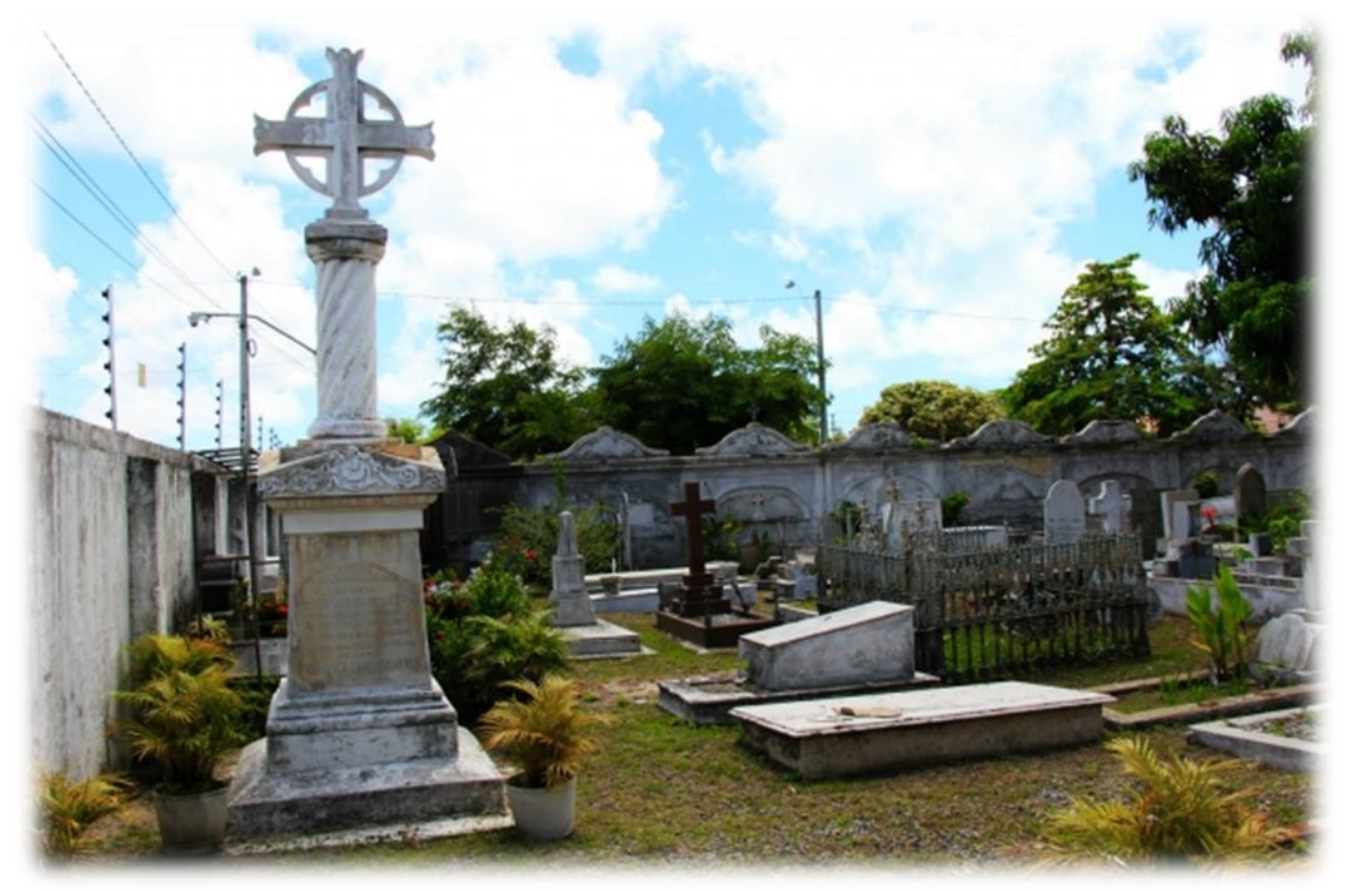

Figura 4: Fotografia do túmulo-monumento do general Abreu e Lima.

Fonte: Foto dos autores, 2014.

O seu poder de atração, sem detrimento de outros aspectos, advém certamente da imponência principalmente em relação ao restante do acervo tumular do local. Os cemitérios ingleses e, portanto, à época, protestantes, apresentavam (e apresentam, salvo singularíssimas exceções) uma estética tumular comprometida com formas sóbrias e comedidas. Tal disposição refletia (e reflete) a concepção (sobretudo anglicana) de morte e seus incontornáveis desdobramentos, haja vista que

O discurso anglicano sobre a morte construiu-se seguindo a tradição eclesiástica e os ensinamentos bíblicos. [...] via a morte basicamente sob três perspectivas: a primeira era que a morte do cristão era uma morte bem-aventurada, pois que morriam no Senhor; a segunda é a

\footnotetext{
${ }^{19}$ Não se encontrou informações fidedignas sobre diversos dados relativos ao monumento e sua construção: autoria, dimensões, custo, época de elaboração, material constitutivo, etc. Desconhece-se, até o momento desta produção, texto (acadêmico ou de outro intuito) que o contemple pela perspectiva que se o está abordando. De certo, apenas, tem-se que sua construção resultou de iniciativa de familiares e amigos admiradores que se uniram e erigiram a homenagem ao general. O que, aliás, está consignado no epitáfio.
} 
que identificava a morte como um sono, um repouso dos fiéis no aguardo da ressurreição eterna; e a terceira concepção era a de que se constituía numa passagem, numa partida desta vida para a vida eterna. A morte bem-aventurada, ou a boa morte, referia-se normalmente a pessoas que faleciam na velhice e que após uma longa existência, morriam rodeadas de filhos e netos e lembradas por suas boas obras. Mesmo as mortes prematuras de crianças e jovens, no final, eram consideradas como "a vontade soberana de Deus", mesmo que oculto e incompreensível à primeira vista, mas pleno da sabedoria do Pai.

Na segunda perspectiva, a morte era concebida como um período de sono dado por Deus, onde o fiel dorme o sono dos justos na paz de Cristo. Morrer tinha o mesmo sentido de dormir, repousar no Senhor, para esperar a ressurreição eterna que estava por vir. Os anglicanos acreditavam que a ressurreição era uma promessa de Jesus Cristo da qual eles participavam enquanto seus seguidores. Ao conceberem a morte como uma passagem para a vida eterna, não se eliminava a possibilidade de tomá-la como um sono, uma rápida transição do homem para uma outra dimensão que garantia a eternidade no seio de Cristo. (...) Havia certa comunicação entre essas duas esferas, garantida, inclusive, através da doutrina da intercessão pelos mortos. (...). Os mortos continuavam vivos na memória dos seus familiares, presentes no cotidiano dos que lhes sobreviviam, permaneciam ligados por laços afetivos e de parentesco. Daí ser compreensível e coerente a falta de ostentação póstuma dos túmulos, uma vez que a crença estabelecida era a de que o fiel ressuscitaria num corpo novo, imperecível, e num outro mundo intangível e eterno (TAVARES, 2015, p. 18-19).

Arte tumular ou arte funerária, que compreende construções feitas para sobreporem-se às sepulturas, é uma forma de representação, da vida e da morte, ligada à cosmovisão de determinado contexto histórico, cultural, ideológico, social e econômico. Ela pode ser constituída por um conjunto de símbolos ou de uma obra narrativa, utilizando-se materiais variados como o mármore, o granito, o ferro fundido, o bronze, entre outros materiais. "É um tipo de construção repleta de simbolismo, facilmente assimilado pelo grande público" (BORGES, 2002, p. 172).

Segundo a autora supramencionada, o estudo dessas construções permite perceber as etapas da transformação da vida social do homem por conterem uma série de imagens e adornos que são cultuados pelas pessoas, segundo sua formação religiosa e moral. Quando impregnados de expressões religiosas, os túmulos traduzem uma mensagem de fé conciliada às lembranças. Quando trazem símbolos cívicos, prestam-se a homenagens póstumas. Para a população, quanto mais imagens e adornos simbólicos o monumento funerário apresentar, maior é seu significado, recebendo, assim, visitas frequentes. Daí advém o grande valor expressivo dos túmulos. No silêncio dos símbolos 
ali presentes, produzidos com certo gosto artístico e de fácil assimilação, eles despertam em seus visitantes os mais profundos e significativos sentimentos (BORGES, 2002).

Os visitantes vivem procurando a luz nas lembranças. Travam uma luta constante e árdua contra o vácuo do esquecimento que os assombram constantemente. Encontram, nos campos santos, aos quais estão enraizados, um espelho de si e da sociedade. Buscam refletir neles suas identidades, seus desejos, sentimentos, emoções, angústias, sofrimentos, sonhos... Veem os cemitérios como senhores e guardiões do tempo, da memória e da história. Que contam, recontam, criam, e recriam, por meio de seus discursos, suas histórias.

Ademais, conforme preceitua Argan (1998), as coisas artísticas têm um valor intrínseco relacionado a certos sinais, ocorrendo uma solidariedade de princípio entre a ação artística e a ação histórica. A análise da obra de arte deve prevalecer à matéria estruturada e ao processo de estruturação. No objeto artístico, percebem-se as ligações que o artista possui com a sociedade de que é parte integrante, segundo as quais são compreendidas as preferências e as ideias artísticas. Ou seja, as escolhas intencionais do artista partem sempre de um olhar individual e social.

Para Brandi (2004), dois momentos devem ser levados em consideração para a criação de uma obra de arte. O primeiro se refere às escolhas, gostos, preocupações, teorias, ideologias do artista, que terá em comum com a época que vive. Já o segundo, refere-se ao tempo em que o artista vive, será ou não reconhecido naquela obra sua, e a validade desta não crescerá nem diminuirá em nada por causa disso.

Por esses parâmetros, o túmulo do general Abreu e Lima oferece possibilidades interpretativas a partir de alguns de seus elementos constitutivos. É uma figura composta por vários elementos: cruz, coluna, lápide e epitáfio.

Aplicando-se de maneira flexível - em relação ao monumento - a metodologia elaborada por Borges em sua obra "Arte Funerária no Brasil (1890-1930): ofício de marmoristas italianos em Ribeirão Preto" (2002), pode-se descrever, com relação à tipologia da sua arquitetura tumular, que se trata de um túmulo monumental por apresentar característica de grandiloquência, qualidades artísticas, decoração apurada. "Monumental" devido à semelhança aos monumentos celebrativos; "grandiloquente" pelos aspectos formais da construção: assentado sobre uma base que ocupa toda a área reservada à carneira, verticalismo, elementos compositivos sobrepostos afunilando para 
o céu; "qualidades artísticas" em face de ser construído sob encomenda e com exclusividade, o que propiciava ao construtor maior liberdade de expressão; finalmente, "decoração apurada", que remete a adornos e a escultura de grande porte, mesmo que única.

Encimando o monumento, sobre o capitel da coluna, está a cruz celta - artefato muito recorrente nos cemitérios protestantes (Figura 5).

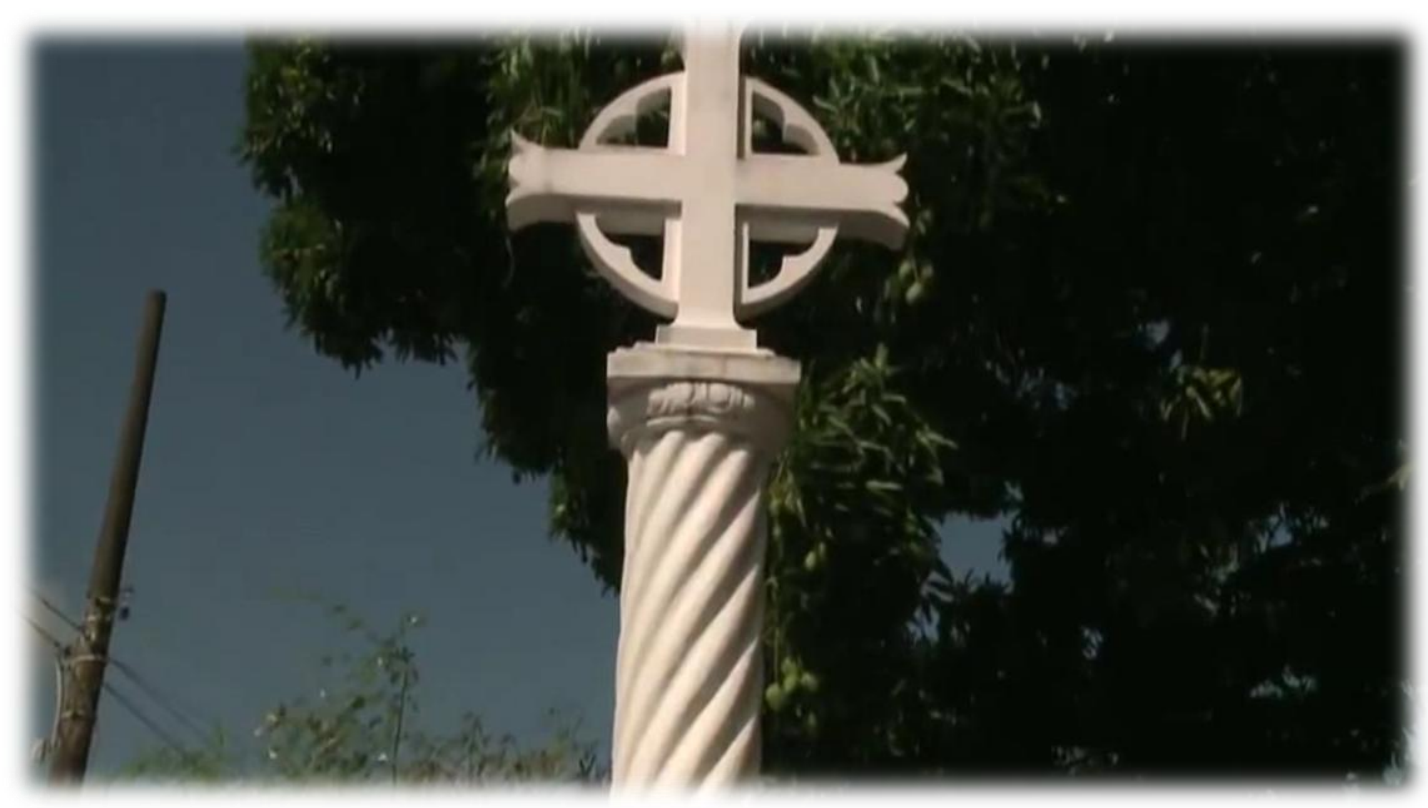

Figura 5: Fotografia de detalhe do monumento.

Fonte: Foto dos autores, 2014.

A Cruz Celta, ou Cruz Céltica, simboliza o povo Celta, e o seu uso é mais remoto do que a cruz cristã como símbolo do cristianismo. É uma cruz com um círculo onde as barras vertical e horizontal se encontram, e representa a espiritualidade focada na criação. Seu uso remonta ao equilíbrio da vida e a eternidade, com a junção dos quatro elementos essenciais: água, terra, fogo e ar.

Hoje, a Cruz Celta também é um dos símbolos do presbiterianismo, e das igrejas reformadas Batista e Anglicana, e representa o nascimento, morte e ressurreição de Cristo. O círculo, que na simbologia pagã representava o sol, agora representa a circularidade da vida, a renovação eterna. Ao usar a Cruz Celta, as igrejas afirmam as sua doutrina e identidade, revelando a sua herança protestante. Nessa perspectiva, a Cruz Celta representa a vida eterna no reino de Deus. 
Outro elemento significativo do monumento é a coluna, com seu fuste torcido em espiral (Figura 6).

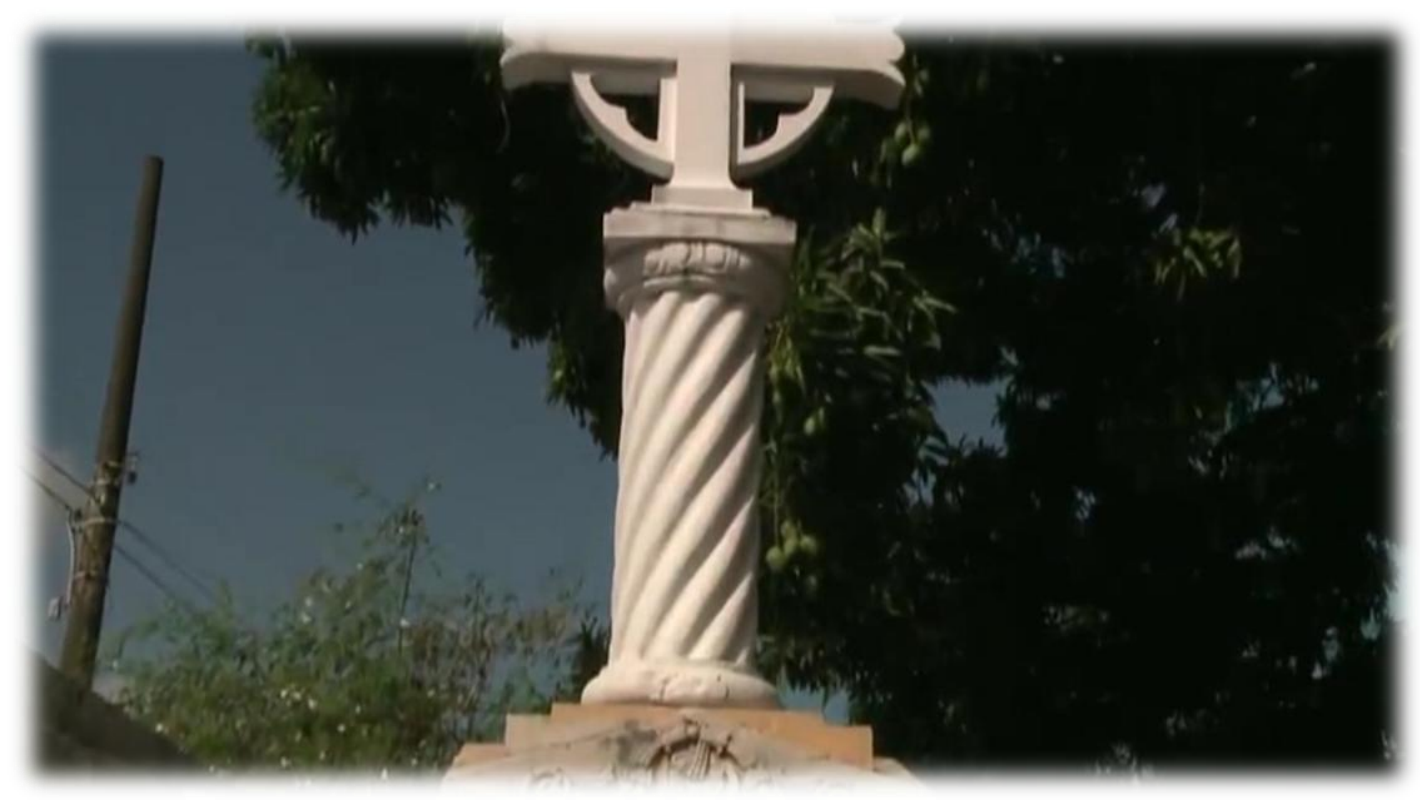

Figura 6: Reprodução de coluna retorcida ou salomônica.

Fonte: Foto dos autores, 2014.

Chamada de Coluna Salomônica, esse tipo de coluna é característica da arquitetura barroca. Ela começa em uma base e termina em um capitel, como a coluna clássica, mas com o fuste retorcido de forma helicoidal que produz um efeito de movimento e dramatismo. A introdução da coluna salomônica no barroco manifesta a condição de movimento. Em muitas ocasiões o fuste é coberto com decoração de folhas de acanto. Os capitéis podem ser de diversas ordens, predominando a compósita e a coríntia. É corrente que seu uso seja mais ornamental que tectônico, pelo que é muito mais comum ela ser usada em retábulos ou adossada a outros adornos.

Abaixo da base da coluna, elementos decorativos estão presentes em outro módulo que compõem o monumento (Figura 7). São arabescos, empregados nos arremates laterais das lajes de mármore epigrafadas existentes nos túmulos simples e nos monumentais. Formam um verdadeiro entrelaçar de linhas, ramagens e flores. São apropriações de flores estilizadas por curvas do estilo art-nouveau, facilmente assimiladas pelo homem comum da belle époque. 


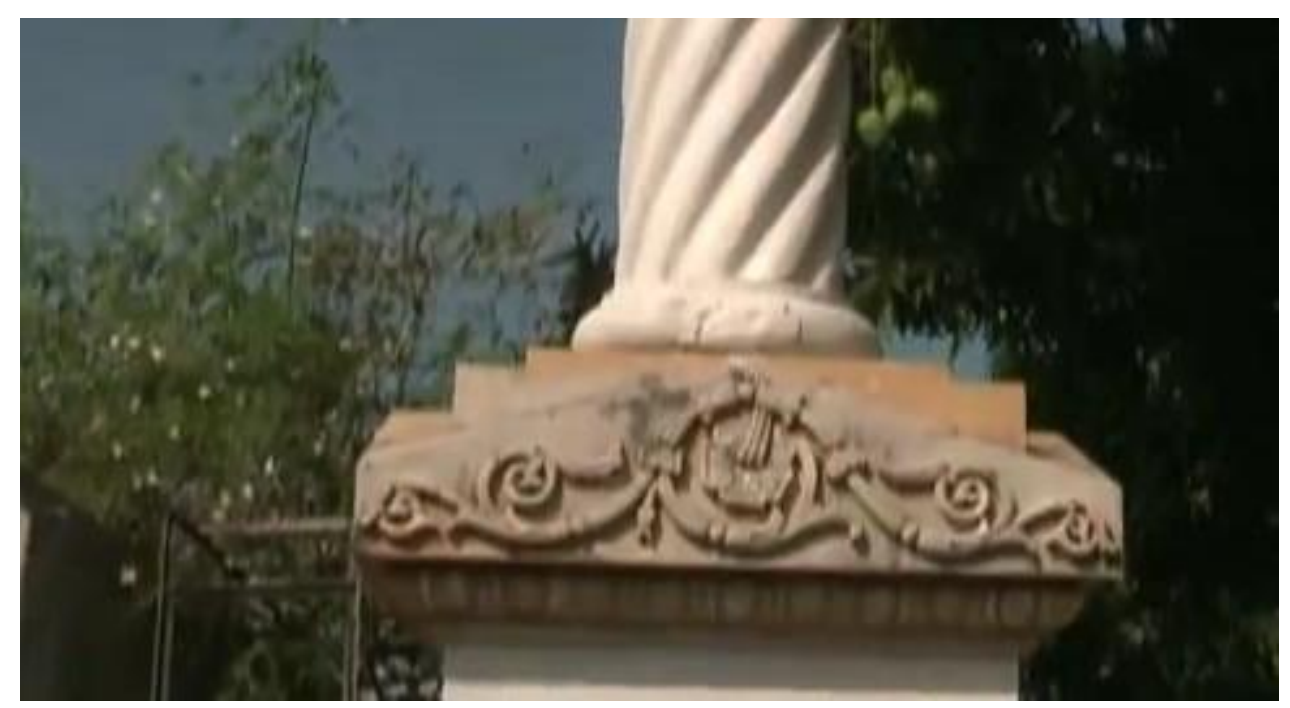

Figura 7: Foto dos arabescos acima da lápide.

Fonte: Foto dos autores, 2014.

A lápide segue ao módulo que contém os arabescos, e contém o epitáfio (Figura 8). Lápide ou lápida é uma pedra que contém uma inscrição (epitáfio) gravada para registrar a morte de uma pessoa, normalmente localizada sobre o túmulo ou anexa a ele. Podem ter também o formato de uma placa de bronze (ou outro metal, alumínio, por exemplo).

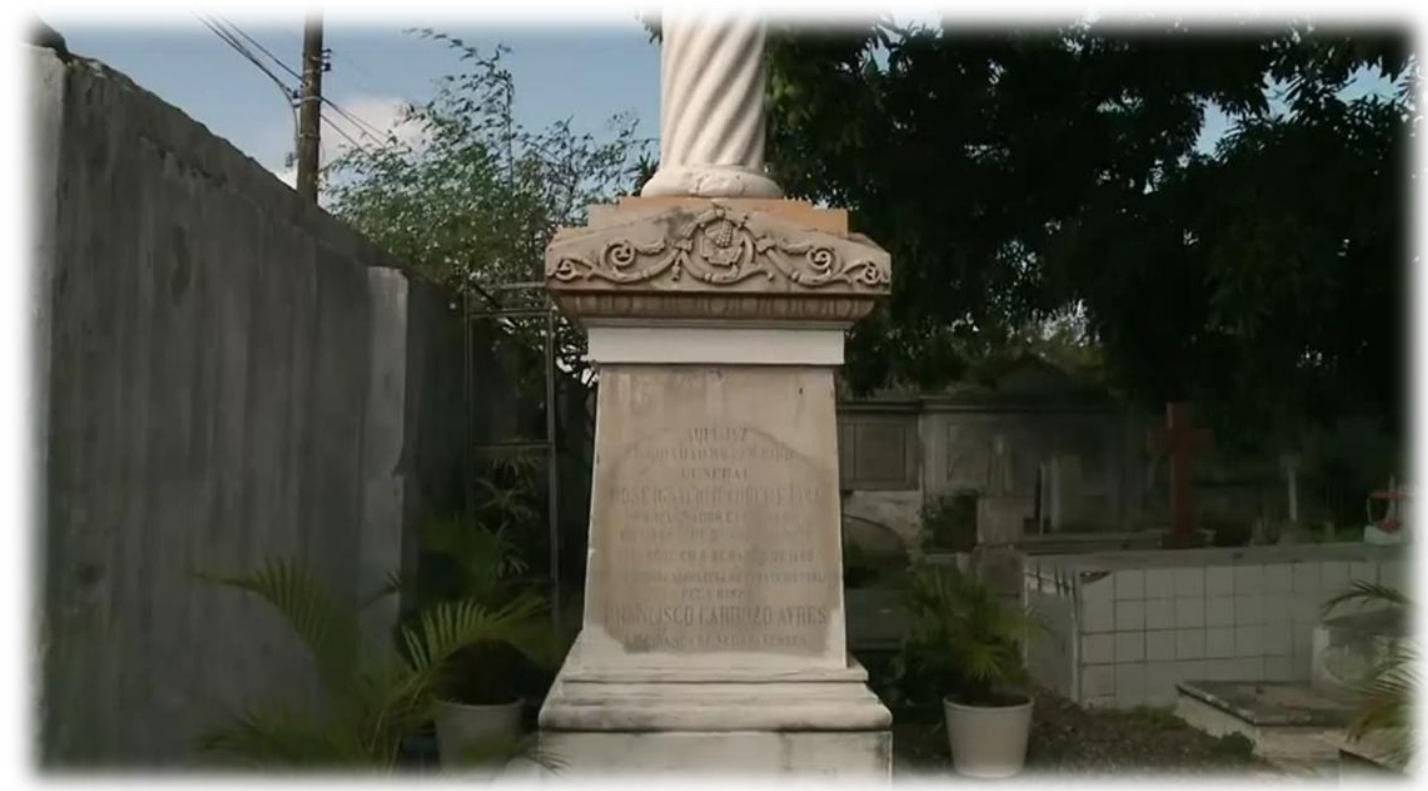

Figura 8: Fotografia de parte do monumento: lápide e epitáfio.

Fonte: Foto dos autores, 2014. 


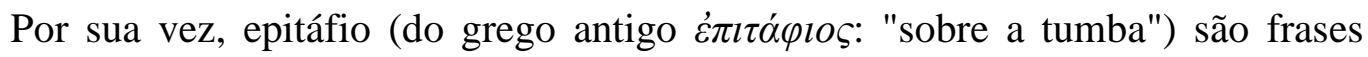
escritas sobre túmulos, mausoléus e campas cemiteriais para homenagear pessoas ali sepultadas. Normalmente, os dizeres são colocados em placas de metal ou pedra.

Os epitáfios apareceram imitando inscrições da Antiguidade clássica, com o objetivo de afirmar a identidade do morto. No século XIX, eles estão ligados à piedade para com o morto, traduzindo um sentimento real profundo de dor por meio de poemas em verso, com elogios intermináveis e com menos detalhes pessoais (BORGES, 2002).

O epitáfio do general (Figura 9), gravado no próprio bloco, é uma inscrição que guarda visão determinada da polêmica resultante dos incidentes que envolveram seu sepultamento.

É composto das seguintes palavras:

Aqui jaz o cidadão brasileiro general José Ignácio d'Abreu e Lima, propugnador esforçado da liberdade de consciência. Faleceu em 8 de março de 1869. Foi-lhe negada sepultura no Cemetério (sic) público pelo bispo Francisco Cardozo Ayres. Lembrança de seus parentes.

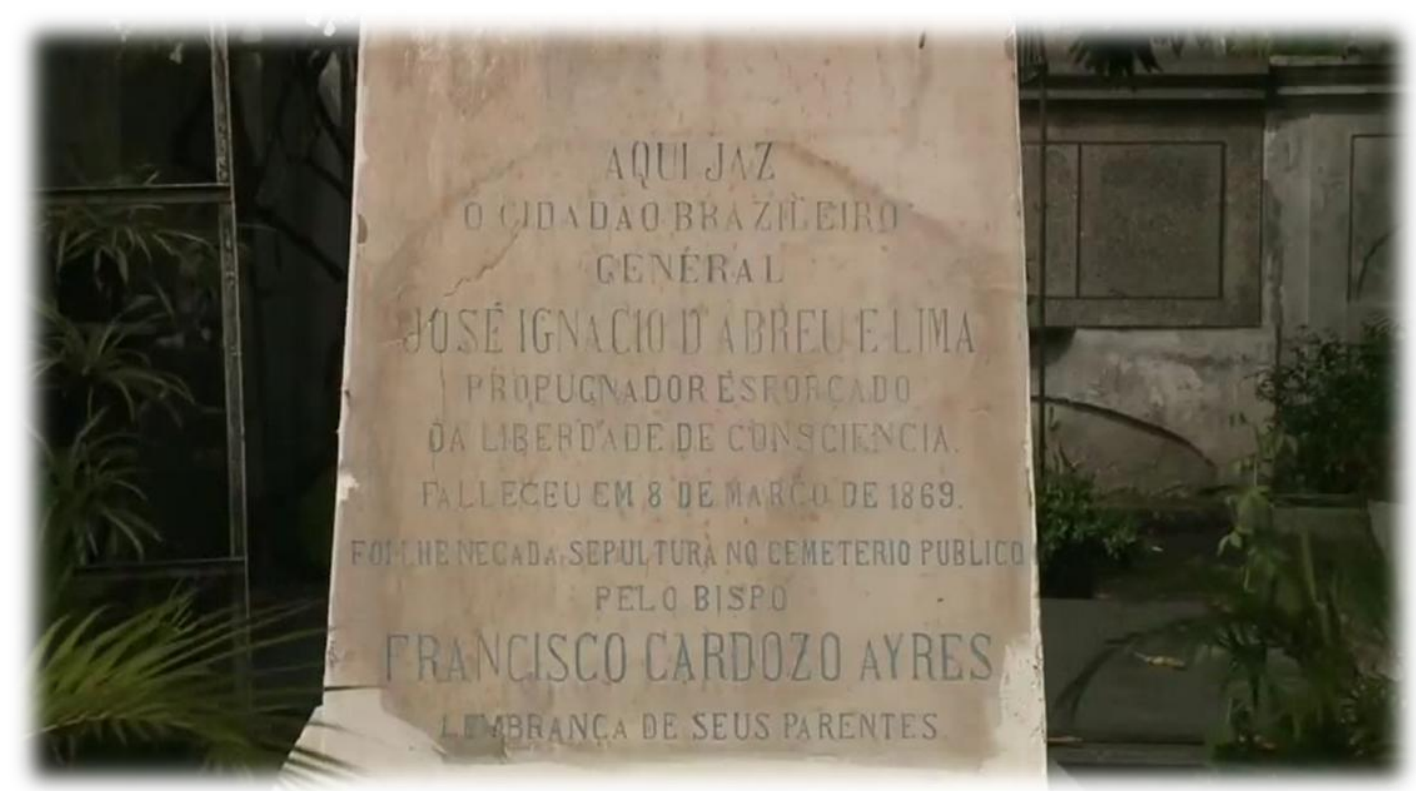

Figura 9: Fotografia do epitáfio de Abreu e Lima.

Fonte: Foto dos autores, 2014.

Se o túmulo não apresenta "evidências alegóricas, de cenários operáticos e de convulsiva dramaticidade" (MOTTA, 2011, p. 280), tão à moda dos túmulos dos cemitérios oitocentistas, a grandiosidade e a representatividade estatuárias residem na reivindicação do reconhecimento a Abreu e Lima; destacam que sua participação entre 
os homens foi de alguma forma maior que outros. Por motivos de divergências com membros da Igreja Católica esse reconhecimento foi ofuscado. Porém, esse incidente não apagou de maneira alguma seus feitos de grande valor. A sua morte, e os fatos que se sucederam a ela, se, por um lado, eclipsaram a importância de alguém cujo desiderato era brilhar, por outro, trouxeram mais elementos para a elaboração social mitificada e enigmática do homem.

\section{CONCLUSÃO}

José Ignácio de Abreu e Lima foi um personagem importante de episódios marcantes e decisivos da história pernambucana, brasileira e sul americana. A história do "mui desassossegado Senhor General” (BRUNI, 2010), repleta de situações-limites, é digna de ser evocada às novas gerações.

No British Cemetery, Abreu e Lima ainda vive de maneira fortemente simbólica. E vive porque de vários modos ligou-se definitivamente àquilo que se é e, também, em certa medida, ao que já não se pode deixar de ser. Posto que, convém (re)lembrar, "O cemitério é um espelho em que os vivos se refletem e se encontram na memória dos mortos. Ali, no silêncio definitivo, podem os mortos ser interrogados e compreendidos no seu legado [...]" (MARTINS, [2005?], p. 1).

O seu túmulo remete a uma história de vida plena de desafios e superações até o final, ao mesmo tempo em que estimula o olhar para além da materialidade e do tempo. A construção de um mausoléu visa o futuro, pretende a perpetuação da memória e o parar do tempo, que escorre como os grãos de areia de uma ampulheta (CATROGA, 1999; BATISTA, 2011). Na combinação de seus comedidos elementos artísticos e simbólicos, há que se compreender um somatório de exaltação e reclamo.

Se, como já foi dito, a arte é uma forma de representação que está ligada à cosmovisão de determinado contexto temporal, histórico, ideológico, social e econômico, interpretativa da relação entre a vida e a morte, o túmulo do general é um testemunho singelo disso: nele, história e arte imbricadas testemunham uma vida singularíssima, destinada à imortalidade pelos seus contemporâneos.

O visitante do British Cemetery do Recife, que numa tarde de outono recifense, após contemplar aquela tumba e repassar na imaginação a significativa história do 
homenageado, poderá depois sair em silêncio pelo portão do Cemitério que conduz para a Avenida Cruz Cabugá com a certeza de que "a morte não prevalece contra a vida nem contra o belo, que dá vida é próprio" (MARTINS, [s. d.], p. 16).

\section{REFERÊNCIAS}

AGUIAR, Cláudio. A Morte do General e o Amor do Bispo. In: Franklin

Távora e o Seu Tempo. São Paulo: Ateliê Editorial, 1997. p. 163-172.

ARANA, Marie. Bolívar: O Libertador da América. São Paulo: Três Estrelas, 2015.

ARGAN, Giulio Carlo, História da Arte como História da Cidade. São Paulo: Editora Martins Fontes, 1998.

BATISTA, Henrique Sérgio de A. Jardim Regado com Lágrima de Saudade: morte e cultura visual na Venerável Ordem Terceira dos Mínimos de São Francisco de Paula (século XIX). Rio de Janeiro: Arquivo Nacional, 2011.

BORGES, Maria Elizia. Arte Funerária no Brasil (1890-1930): ofício de marmoristas italianos em Ribeirão Preto = Funerary Art in Brazil (1890-1930): italian marble carver craft in Ribeirão Preto. Belo Horizonte: C/Arte, 2002.

BRANDI, Cesare. Teoria da Restauração. São Paulo: Ateliê Editorial, 2004.

BRUNI, Sérgio. O Mui Desassossegado Senhor General: a vida de José Inácio de Abreu e Lima. Rio de Janeiro: Fundação Getúlio Vargas, 2010.

CASTRO, Moacir Werneck de. O Libertador: a vida de Simon Bolívar. Rio de Janeiro: Rocco, 1988.

CATROGA, Fernando. O Céu da Memória - Cemitério Romântico e Culto Cívico dos Mortos em Portugal (1756-1911). Coimbra: Minerva, 1999.

CHACON, Vamireh. Abreu e Lima: General de Bolívar. $3^{\text {a }}$ ed. rev. aum. Recife: Companhia Editora de Pernambuco, 2007.

COLI, Jorge. O Que é Arte. 15ª ed. São Paulo: Brasiliense, 1995. (Coleção Primeiros Passos, 46.)

COSTA, Francisco Augusto Pereira da. Diccionário Biographico de Pernambucanos Celebres. Recife: Typographia Universal, 1882. Disponível em: <http://www2.senado.leg.br/bdsf/item/id/221687> Acesso em: 22 nov. 2015.

FONSECA, Edson Néri da. Nota na contracapa. In: LIMA FILHO, Andrade; PEREIRA, Nilo. O Bispo e o General. $2^{\mathrm{a}}$ ed. rev. Recife: Universidade Federal de Pernambuco, Editora Universitária, 1975. 
LIMA FILHO, Andrade; PEREIRA, Nilo. O Bispo e o General. $2^{\text {a }}$ ed. rev. Recife: Editora Universitária, 1975.

MARTINS, José de Souza. História e Arte no Cemitério da Consolação. São Paulo: Prefeitura da Cidade de São Paulo/Secretaria de Cultura, [s. d.].

MOTTA, Antonio. Museu da Morte: patrimônios familiares e coleções. In: MAGALHÃES, Aline M.; BEZERRA, Rafael Z. Museus Nacionais e os Desafios Contemporâneos. Rio de Janeiro: Museu Histórico Nacional, 2011. p. 280-295.

OLIVEIRA, Tatiane Maria B. de. Abreu e Lima: um herói entre a história e a ficção. 2015. 50 f. Monografia (Trabalho de Conclusão de Curso II) - Curso de Letras, Universidade Federal de Pernambuco, Recife, 2015.

RODRIGUES, Cláudia. Lugares dos Mortos na Cidade dos Vivos: tradições e transformações fúnebres no Rio de Janeiro. Rio de Janeiro: Secretaria Municipal de Cultura, Departamento Geral de Documentação e Informação Cultural, Divisão de Editoração, 1997.

Nas Fronteiras do Além: a secularização da morte no Rio de Janeiro (séculos XVIII e XIX). Rio da Janeiro: Arquivo Nacional, 2005.

TAVARES, Davi Kiermes. Ingleses no Brasil: Estilo de Viver, Estilo de Morrer. Revista Seminário de História da Arte. Pelotas, n. 5, 2015. Disponível em: 〈https://periodicos.ufpel.edu.br/ojs2/index.php/Arte/issue/view/474/showToc> Acesso em 20 dez. 2015.

Uma Necrópole Esquecida e os Valores Para a Sua Conservação: o British Cemetery do Recife em Perspectiva. 2016. 222 f. Dissertação (Mestrado em Memória Social e Patrimônio Cultural) - Programa de Pós-Graduação em Memória Social e Patrimônio Cultural, Instituto de Ciências Humanas, Universidade Federal de Pelotas, Pelotas, 2016.

VALLADARES, Clarival do Prado. Arte e Sociedade nos Cemitérios Brasileiros: um estudo da arte cemiterial ocorrida no Brasil desde as sepulturas de igrejas e as catacumbas de ordens e confrarias até as necrópoles secularizadas. Rio de Janeiro: Conselho Federal de Cultura/MEC, 1972. vol. II.

VIEIRA, David Gueiros. O Protestantismo, a Maçonaria e a Questão Religiosa no Brasil. $3^{a}$ ed. Brasília: Editora Universidade de Brasília, 1998.

VOVELLE, Michel. Imagens e Imaginários na História - Fantasmas e certezas nas mentalidades desde a Idade Média até o século XX. São Paulo: Ática, 1997. 